\title{
Görsel Sanatlar Dersinde Öğrencilerin Etkileşimli Tahtaya Yönelik Tutumlarının Farklı Değişkenler Açısından İncelenmesi*
}

\section{Examining the Attitudes of the Students towards the Smart Boards in Terms of Different Variables in the Visual Arts Lesson}

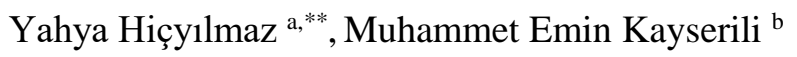 \\ ${ }^{a}$ Dr. Öğr. Üyesi, Van Yüzüncü Yıl Üniversitesi Eğitim Fakültesi, Güzel Sanatlar Eğitimi, Van/Türkiye \\ ORCID: 0000-0003-3453-9998 \\ b Doç. Dr., Atatürk Üniversitesi, Eğitim Fakültesi, Güzel Sanatlar Eğitimi, Erzurum/Türkiye. \\ ORCID: 0000-0003-3072-2357
}

\section{MAKALE BILGİSI}

\section{Makale Geçmişi:}

Başvuru tarihi: 27 Eylül 2018

Düzeltme tarihi: 09 Ekim 2018

Kabul tarihi: 08 Kasım 2018

\section{Anahtar Kelimeler:}

Etkileşimli tahta,

Tutum,

Görsel sanatlar

\section{ÖZ}

$\mathrm{Bu}$ araştırmada Görsel Sanatlar dersinde öğrencilerin etkileşimli tahtaya yönelik tutumlarının farklı değişkenler açısından incelenmesi amaçlanmıştır. Araştırma, 2014-2015 eğitim-öğretim yılında Muş ili merkeze bağlı ortaöğretim kurumlarında etkileşimli tahta ile Görsel Sanatlar eğitimi alan 251 öğrenci ile yürütülmüştür. Araştırmanın amacına bağlı olarak yeni bir ölçeğe ihtiyaç duyulmuştur. Bu doğrultuda Tataroğlu (2009) tarafindan geliştirilen Matematik dersinde Akıllı Tahtaya Yönelik Tutum Ölçeğinin içerik ve görünüş geçerliği bakımından Görsel Sanatlar dersine uyarlanarak kullanılmıştır. Elde edilen bulgular ve yorumlara dayalı olarak varılan sonuçlar göre, öğrencilerin etkileşimli tahtaya yönelik tutumlarının olumlu yönde ve orta düzeyde olduğu belirlenmiştir. Öğrencilerin etkileşimli tahtaya yönelik tutumları, etkileşimli tahta ile öğrenim görme süresi değişkenine göre istatistiksel olarak anlamlı bulunmuştur. Cinsiyet, sınıf düzeyi, etkileşimli tahta kulanım sıklığı, Görsel Sanatlar ders başarısı değişkenlerinde ise istatistiksel olarak anlamlı bir farklılık görülmemiştir.

\section{A B S T R A C T}

In this study, it has been aimed to examine the attitudes of the students towards the smart boards in terms of different variables in the Visual Arts lesson. The study has been conducted with 251 students who take Visual Arts education through smart boards in secondary schools in the central district of Muş in 2014-2015 education year. A new scale was required in accordance with the aim of the study. In this respect, Attitude Scale Towards Smart Board in Mathematics Course developed by Tataroğlu (2009) was used by adapting to Visual Arts course in terms of content and appearance validity. According to the results based on the findings and review, it has been determined that the attitudes of the students towards the smart boards are positive and at an intermediate level. Students' attitudes towards smart boards, with reference to the studying time with interactive board variable, are statistically significant. However, a statistically significant difference hasn't been detected according to variables such as gender, grade level, frequency of smart board using and success of Visual Arts lesson.

\section{Giriş}

Bilgi çağı ya da teknoloji çağı olarak da adlandırılan 21 . yüzyıl, insan hayatının her alanını ilgilendiren hızlı bir gelişme göstermektedir. $\mathrm{Bu}$ teknolojik gelişmeler tüm alanlarda yenilikler ve değişimler meydana getirmiştir. Her geçen gün yenilenen teknolojilere ayak uydurmak zorunlu hale gelmiştir. Bu teknolojilere ayak uydurmayanlar çağın gerisinde kalıp toplumlar arası rekabeti sağlayamaz duruma gelmişlerdir.

\footnotetext{
* Bu çalışma, 2015 yılında Atatürk Üniversitesi Eğitim Bilimler Enstitüsü tarafından kabul edilen "Görsel sanatlar dersinde ögrrencilerin akıllı tahtaya yönelik tutumları ve öğretmen görüşlerinin incelenmesi” adlı Yüksek Lisans tezinden türetilmiştir.

** Sorumlu yazar/Corresponding author.

e-posta: yahya-04@windowslive.com
} 
Bilginin hızlı bir şekilde çoğaldığı ve yayıldığı günümüzde, bilimsel ve teknolojik gelişmeler, bilginin nicelik ve nitelik açısından sürekli gelişmesini sağlamaktadır. Bilgiye paralel olarak teknoloji gelişiminin de baş döndürücü şekilde ilerlediği ve yaşamın hemen her alanında teknolojik gelişmelerin etkisini gösterdiği bir gerçektir. Bilginin küresel çaptaki dolaşımında, teknolojinin çok önemli bir işlevi olduğu bilinmektedir (Birişçi ve Karal, 2010; Güzeller ve Korkmaz, 2007; Halis, 2002). Bu açıdan teknolojik gelişmeler bir dönüşüm süreci ortaya çıkartmıştır. Bu süreç, birçok tehdidi beraberinde getirmekle birlikte insanoğluna birçok firsat da sunmuştur. Dönüşümün hızlı bir şekilde ilerlediği bu süreçte ortaya çıkan tehditlere karşı koymak, firsatlardan yararlanmak ve insana daha yaşanabilir bir gelecek sunmak için eğitim sistemlerinin de bu duruma ayak uydurması kaçınılmaz olmuştur (Odabaşı, 2010). Bu dönüşümler, eğitim kurumlarının tüm yönlerini etkilemektedir. Bireyleri çeşitli alanlarda istihdam eden sistemler, eğitim kurumlarının yeni teknolojileri kullanabilen bireyler yetiştirmesini beklemektedir. Bu beklenti, sadece teknoloji kullanımını öğretmeyi değil, aynı zamanda teknolojiyi eğitim-öğretim uygulamalarında da kullanmayı içermektedir. (Hançer, 2005). Eğitim-öğretimde bilgisayarla birlikte internetin kullanılması, bilgiye ulaşımı kolaylaştırıp hızlandırmakta, eğitim uygulamalarına yeni imkânlar sağlayarak kullanılan yöntemleri öğrenme-öğretme kaynaklarını ve ortamlarını da zengin hale getirmektedir (Engin, Tösten ve Kaya, 2010; Koşar ve Çiğdem, 2003). Ögrretmenlerin yeni teknolojileri tanıyıp kullanmasıyla birlikte okullardaki teknolojilerin kullanımı yaygınlaşmakta ve bu durum süreç içerisinde daha da önem kazanmaktadır (Kennewell ve Morgan, 2003).

Görsel Sanatlar sınıfında teknoloji entegrasyonu için çok sayıda araç bulunmaktadır. Ancak etkileşimli (akıllı) tahta, FATİH projesi ile birlikte bu sınıflarda yaygınlaşmaya başlanmıştır. Etkileşimli tahta elektronik, interaktif bir tahtadır. Başka bir deyişle etkileşimli beyaz tahta, bir bilgisayara ve projektöre bağlı öğretim aracı olarak bilinmektedir (Balta ve Duran, 2015).

Görsel Sanatlar ders süresinin yeterli olmadığı bilinmektedir. Dolayısıyla süresinin verimli bir şekilde geçirilmesi önem taşımaktadır. Özellikle sanat tarihi ve sanat eleştirisi çalıșmalarında etkileşimli tahtadan etkili bir şekilde yararlanılabilir (Kuzminsky, 2008). Sanat eserlerinin bir kopyasını görüntüleme ve sanat eserleri içerisindeki çıkarımları okumak ve yorumlamak için etkileşimli tahta kullanılabilir. Ayrıca etkileşimli tahta üzerinde; kopyalama, yapıştırma, el yazısı notları alma, bunları metin haline dönüştürme, kaydetme, geri getirme gibi çeşitli pratik eylemler gerçekleştirilebilir. Bu açıdan Görsel Sanatlar dersinde etkileşimli tahtaların kullanılması öğretmeöğrenme süreci için büyük önem taşımaktadır.

Öğretim teknolojileri arasına giren ve son yıllarda sınıflarda kullanımı artmakta olan etkileşimli tahtalar, önceki teknolojilere göre öğrenme-öğretme ortamında daha akıcı bir sunum özelliği göstermektedir. Öğrenme-öğretme ortamında öğrenci-öğretmen etkileşimi açısından bakıldığında, etkileşimli tahta kullanımı öğretmenin öğrencileri daha iyi gözlemleyerek sorularına daha fazla cevap verme olanağı sunmaktadır (Gillen, Kleine, Littleton, Mercer ve Twiner, 2007). Öğrencilerin etkileşimli tahtaya yönelik tutumlarının yüksek olması nitelikli birey yetiştirme ve teknolojinin eğitim-öğretim sistemine entegrasyonun başarılı bir şekilde hedefe ulaşmasında kolaylaştırıcı rol oynayacaktır. Dolayısıyla Görsel Sanatlar derslerinde öğrencilerin etkileşimli tahtaya yönelik tutumlarının belirlenmesi öğrenme-öğretme sürecinin iyileştirilmesine bir yol haritası sunabileceği düşünülmektedir.

Yurtiçinde ve yurtdışında eğitimde etkileşimli tahta ile ilgili farklı disiplinlerde birçok araştırma yapılmıştır (Balta ve Duran, 2015; Polat ve Özcan, 214; Tatlı ve Kılıç, 2013; Yorgancı ve Terzioğlu, 2013; Yıldızhan 2013; Bulut ve Koçoğlu, 2012; ; Lau, 2011; Manny-Ikan, Tikochinski, Zorman, ve Dogan, 20011; Ateş, 2010; Birişçi, ve Karal, 2010; Odabaş1, 2010; Güzeller ve Korkmaz, 2007; Kennewell ve Beauchamp, 2007; Armstrong, ve Arkadaşları, 2005; Thomsan ve Flecknoe, 2003; Beelend,2002; Kennewell ve Morgan, 2003; Levy, 2002; Bell, 1998).

Teknolojinin sanat eğitimi sürecine entegrasyonu ile ilgili farklı çalışmalar bulunmaktadır (Agyeman, 2015; Değerli, 2015; Hiçyılmaz ve İnam Karahan, 20016; Yılmaz ve Bilici, 20016; Avc1, 2013; Athanasiadis, Maria ve Efstathios, 2011). Fakat ülkemizde Görsel Sanatlar dersinde etkileşimli tahta kullanımı ile ilgili yapılan çalışmalar çok azdır. $\mathrm{Bu}$ konu ile ilgili yapılan araştırmalar incelendiğinde Hiçyılmaz ve Kayserili (2017) sanat eğitiminde akıllı tahta kullanımına ilişkin öğretmen görüşünü incelemiştir. Akgül (2013) Görsel Sanatlar eğitiminde akıllı tahta kullanımının öğrenci başarısı üzerindeki etkisini araştırmıştır. Tereni (2011) Okul öncesi Görsel Sanatlar eğitiminde akıllı tahta kullanılması ile ilgili bir vaka çalışması yapmıştır. Bu açıdan Görsel Sanatlar dersinde öğrencilerin etkileşimli tahtaya yönelik tutumlarını belirleyen yeni bir ölçeğin geliştirilmesi ve öğrencilerin etkileşimli tahtaya yönelik tutumlarının farklı değişkenler açısından incelenmesi önem taşımaktadır. Bu doğrultuda bu araştırmada, Görsel sanatlar dersinde öğrencilerin etkileşimli tahtaya yönelik tutumlarının farklı değişkenler açısından incelenmesi amaçlanmıştır. Araştırmanın genel amacına uygun olarak aşağıdaki alt problemler belirlenmiştir:

(i) Görsel Sanatlar dersinde etkileşimli tahta kullanılan sınıflardaki öğrencilerin etkileşimli tahtaya yönelik tutumları ne düzeydedir?

(ii) Öğrencilerin etkileşimli tahtaya yönelik tutum ölçeği puanları; cinsiyetlerine, sınıf düzeylerine, etkileşimli tahta ile öğrenim görme süresine, etkileşimli tahta kullanım sıklığına, Görsel Sanatlar ders başarısına göre farklılık göstermekte midir?

\section{Yöntem}

$\mathrm{Bu}$ araştırma betimsel nitelikte olup tarama modeli uygulanmıştır. "Tarama modeli, geçmişte ya da halen var olan bir durumu var olduğu şekliyle betimlemeyi amaçlayan araştırma yaklaşımıdır. Araştırmaya konu olan olay, birey veya nesneler, kendi koşulları içinde hiçbir müdahale ve değiştirme söz konusu olmadan, herhangi bir etki çabası olmadan var olduğu şekliyle tanımlanmaya çalışılır" (Karasar, 1991: 77).

\section{1. Çalışma Grubu}

Araştırmanın çalışma grubu 2014-2015 eğitim-öğretim yılında Muş ili merkezine bağlı üç orta öğretim kurumunda etkileşimli tahta ile Görsel Sanatlar eğitimi alan 9., 10. ve 11. sınıfta öğrenim gören toplam 251 öğrenciden oluşmaktadır. 
Çalışma grubu atölye ortamında etkileşimli tahta ile düzenli bir şekilde eğitim verilen orta öğretim okullarından seçilmiştir. Çalışma grubuna 12. sınıf öğrencilerinin alınmama nedeni etkileşimli tahtanın bu sınıf düzeyinde yeterince kullanılmıyor olmasıdır. Çalışma grubunu oluşturan öğrencilerin demografik bilgileri Tablo 1'de verilmiştir.

Tablo 1. Öğrencilerin Demografik Özellikleri

\begin{tabular}{lcc}
\hline Cinsiyet & F & $\%$ \\
\hline K1z & 131 & 52,2 \\
Erkek & 120 & 47,8 \\
Toplam & 251 & 100,0 \\
\hline Sinıf Düzeyi & & \\
\hline 9.sinif & 76 & 30,3 \\
10.sinıf & 70 & 27,9 \\
11.sinıf & 105 & 41,8 \\
Toplam & 251 & 100,0 \\
\hline
\end{tabular}

Tablo 1 incelediğinde örneklem grubunu oluşturan öğrencilerin \% 52,2'sinin erkek, \% 47,8'inin ise k1z öğrencilerden oluştuğu görülmektedir. Tablo incelenmeye devam edildiğinde 9. Sinıf ile 10. sinıfta bulunan öğrencilerin sayılarının birbirine yakın olduğu görülmekte fakat 11. sınıftaki öğrencilerin sayısının diğer sınıflara göre daha fazla olduğu görülmektedir.

\subsection{Veri Toplama Arac1}

Öğrencilerin Görsel Sanatlar dersinde etkileşimli tahtaya yönelik tutumlarını belirlemek amaciyla 2009 yılında Tataroğlu, Erduran tarafından geliştirilen Matematik Dersinde Akılı Tahtaya Yönelik Tutum Ölçeği kullanılmıştır. $\mathrm{Bu}$ araştırmada temel alınan ölçek derinlemesine incelenmiştir. Ölçeği içerik ve görünüş geçerliliği kapsamında Görsel Sanatlar dersine uyarlamak amaciyla üç alan uzman görüşüne başvurulmuştur. Uzman kişilerin görüşleri doğrultusunda ölçekte gerekli değişiklikler yapılmıştır. Ölçeğin Görsel Sanatlar dersine uyarlanması esnasında ölçekteki maddelerin özneleri değiştirilmiştir. Maddelerinin özneleri değiştirilmiş olan tutum ölçeği, farklı bir örneklem gruba uygulanmıştır. Bu iki nedenden dolayıdır ki ölçeğin geçerlik ve güvenirliklerine tekrar bakılmıştır.

Her bir madde "Tamamen Kat1lyyorum", "Katıliyorum", "Kısmen Katıliyorum", "Katılmiyorum" ve "Tamamen Katılmıyorum” şeklinde sunulmuştur.

Ölçeğin yapısal ve faktöriyel geçerliliğini sağlamak amacıyla açımlayıcı faktör analizi ile başlanmıştır. AFA analizi sonucunda KMO değerinin $(, 880)$ olduğu görülmüştür. Analize alınan 22 maddenin dört faktör altında toplandığ 1 görülmüştür. Faktör (Varimax) döndürme sonrasında ölçeğin birinci faktörünün 6 maddeden, ikinci faktörünün 7 maddeden, üçüncü faktörün 7 maddeden, dördüncü faktörünün 2 maddeden oluştuğu görülmüştür. Belirlenen faktörlerden birincisi ölçeğe ilişkin toplam varyansın (Total Variance Explained) \%31,415'ini, ikincisi $\% 15,958$ 'ini, üçüncüsü \%6,905'ini ve dördüncüsü \%6,181'ini açıklamaktadır. Maddelerin döndürme sonrası yük değerleri 0,519 ile 0,931 arasında değişmekte, maddelerle ilgili olarak tanımlanan dört faktörün ortak varyanslarının ise 0,327 ile 0,910 arasında değiştiği gözlemlenmiştir. Bu faktörlerden birincisi "Görsel Sanatlar dersinde etkileşimli tahtaya yönelik olumlu tutum boyutu”, ikincisi "Görsel Sanatlar dersinde etkileşimli tahtaya yönelik olumsuz tutum boyutu”, üçüncüsü "Görsel Sanatlar dersinde etkileşimli tahtaya yönelik motivasyonel etki boyutu", dördüncüsü "Görsel Sanatlar dersinde etkileșimli tahtanın ders başarısı üzerine etki boyutu" olarak adlandırılmıştır.

Ölçeğin ayrıcılık gücünü belirlemek için madde analizi yapılmıştır. Yapılan analiz sonucunda tutum ölçeğinin düzetilmiş madde toplam korelasyonlarının 0,338 ile 0,666 arasında sıralandığ 1 görülmüştür. Sonuç olarak ölçeğin geçerlik çalışması kapsam geçerliği ve yapı geçerliği olarak iki aşamada sunulmuştur. Kapsam geçerliği alan uzmanlarının görüşleri alınarak sağlanmıştır. Ölçeğin yapı geçerliği ise açımlayıcı faktör analizi yapılarak sağlanmıştır. Ölçeğin güvenirliğini sağlamak için Cronbach's Alpha tekniğinden faydalanılarak iç tutarlılık katsayıları $(\alpha)$ hesaplanmıştır. Ölçekten elde edilen puanların iç tutarlığını değerlendirmek amaciyla hesaplanan Cronbach's Alpha katsayıs1, 0.890 olarak bulunmuştur. $\mathrm{Bu}$ analizler doğrultusunda hazırlanan ölçeğin, geçerli ve güvenilir olduğu kabul edilmiştir.

\subsection{Verilerin Analizi}

Araştırmada veri toplama aracı olarak; "Görsel Sanatlar Dersinde Etkileşimli Tahtaya Yönelik Tutum Ölçeği”, demografik bilgileri öğrenmek amacıyla "Kişisel Bilgi Formu" kullanılmıștır. Bu formlardan elde edilen veriler kodlanıp SPSS 17.0 paket programına girilmiştir ve analizler bu program aracılığı ile yapılmıştır.

Ölçekte yer alan olumlu maddeler 5-4-3-2-1, olumsuz maddeler ise 1-2-3-4-5 şeklinde puanlanmıştır. Olumsuz maddelerin puan değerleri ters çevrilmiştir. Örneğin olumsuz bir maddeyi "tamamen katılıyorum" olarak cevaplayan bir öğrencinin puanı 5'ten 1'e; "Tamamen Katılmıyorum" olarak cevaplayan bir öğrencinin puanı ise 1 'den 5'e dönüştürülmüştür.

Ölçekte elde edilen puanlar "Düşük", "Orta", "Yüksek" olmak üzere üç gruba ayrılmıştır. Puanların gruplandırılmasında ortalama ve bir standart sapma esas alınmıştır. Buna göre "ortalamanın bir standart sapma altında veya daha düşük puana sahip olanlar $(\leq 67)$ düşük; bir standart sapma veya daha yüksek puana sahip olanlar $(\geq 97)$ yüksek; \pm 1 standart sapma aralığında kalanlar (68-96) orta düzey tutum olarak atanmışlardır." Analizlere başlanmadan önce verilerin normallik değerlerine bakılmıştır. Kolmogorov-Smirnov testinin $\mathrm{p}>0.05$ önem düzeyinde anlamsız olması verilerin normal dağıldığına işaret etmektedir. $\mathrm{Bu}$ doğrultuda araştırmacının amacına bağlı olarak t-testi, Tek Yönlü ANOVA testi kullanılmıştır. Ayrıca anlamlı farkın hangi gruplar arasında olduğu belirlemek amacıyla post-hoc testleri kullanılmıştır.

\section{Bulgular ve Yorumlar}

$\mathrm{Bu}$ bölümde, araştırmadan elde edilen verilerin değerlendirilmesi sonucu ortaya çıkan bulgular ve bunların istatistiksel analizleri sunulmuştur.

1. Görsel Sanatlar Dersinde Etkileşimli Tahta Kullanılan Sinıflardaki Öğrencilerin Etkileşimli Tahtaya Yönelik Tutumları Ne Düzeydedir? Şeklindeki Birinci Alt Probleme Ilişkin Elde Edilen Bulgular ve Yorumlar 
Tablo 2'de öğrencilerin Görsel Sanatlar dersinde etkileşimli tahtaya yönelik tutum puanlarına ait veri analizlerine yer verilmiştir.

Tablo 2. Görsel Sanatlar Dersinde Etkileşimli Tahtaya Yönelik Tutum Puanları

\begin{tabular}{cccccccc}
\hline Tutum & $\mathrm{N}$ & $\overline{\mathrm{X}}$ & S.s. & Varyans & SH & Max. & Min \\
\cline { 2 - 7 } puan1 & 251 & 82,66 & 15,15 & 229,6 &, 9564 & 110,0 & 37,0 \\
\hline
\end{tabular}

Tablo 2 incelendiğinde, ölçekten elde edilen puanların ortalaması 82,66'dır. Bu değerden öğrencilerin etkileşimli tahtaya yönelik tutumlarının orta düzeyde (68-96) olumlu yönde olduğu anlaşılmaktadır.

2. Öğrencilerin Etkileşimli Tahtaya Yönelik Tutum Ölçeği Puanlarl Cinsiyetlerine, , Sinıf Düzeylerine, Etkileşimli Tahta Ile Öğrenim Görme Süresine, etkileşimli Tahta Kulanım Sıklığına, Görsel Sanatlar Ders Başarısına Göre Farklılık Göstermekte midir? Şeklindeki Ikkinci Alt Probleme Ilişkin Elde Edilen Bulgular ve Yorumlar

Öğrencilerin etkileşimli tahtaya yönelik tutum puanları arasında cinsiyete göre anlamlı bir farklılık olup olmadığını belirlemek amacıyla t- testi yapılmıştır. Tablo 3 'te t- testi sonuçları verilmektedir.

Tablo 3. Öğrencilerin Cinsiyetlerine Göre Etkileşimli Tahtaya Yönelik Tutumlarına İlişkin t-Testi Sonuçları

\begin{tabular}{lccccc}
\hline Cinsiyet & $\mathrm{N}$ & $\overline{\mathrm{X}}$ & S.s. & $t$ & $\mathrm{p}$ \\
\hline K1z & 131 & 84,00 & 13,91 & 1,474 &, 142 \\
Erkek & 120 & 81,19 & 16,33 & & \\
\hline
\end{tabular}

Tablo 3 incelendiğinde, Görsel Sanatlar dersinde etkileşimli tahtanın kullanıldığı sınıflarda öğrencilerin etkileşimli tahtaya yönelik tutumlarının cinsiyete göre anlamlı bir farklılık gösterip göstermediğini belirlemek için yapılan bağımsız örneklemler $\mathrm{t}$ - testi sonucunda aradaki farkın anlamlı olmadığı bulunmuştur $(\mathrm{t}=1,474, \mathrm{p}>.05)$.

Öğrencilerin etkileşimli tahta tutum ölçeği puanları ile sınıf düzeyi arasında anlamlı bir fark olup olmadığını belirlemek amacıyla Tek Yönlü Varyans analizi (ANOVA) uygulanmış ve bulgular Tablo 4'te verilmiştir.

Tablo 4. Öğrencilerin Sınıf Düzeyine Göre Etkileşimli Tahtaya Yönelik Tutum Ölçeği Puanları Arasındaki Farka İlişkin Tek Yönlü Varyans Analizi Sonuçları (ANOVA)

\begin{tabular}{lcccccc}
\hline Sinıf Seviyesi & $\mathrm{N}$ & $\overline{\mathrm{X}}$ & S.s. & $\mathrm{F}$ & $\mathrm{p}$ & Fark \\
\hline 9. Sinıf & 76 & 84,1 & 14,7 & & & \\
\cline { 1 - 4 } 10. Sinif & 70 & 82,7 & 17,1 & \multirow{2}{*}{, 512} & - \\
\cline { 1 - 4 } 11. Sinif & 105 & 81,5 & 14,0 & & & \\
\hline
\end{tabular}

Tablo 4 incelendiğinde, öğrencilerin etkileşimli tahtaya yönelik tutum ölçeği puanları sınıf düzeyine göre aralarındaki farka ait $F$ değeri ,672 olarak p>.05 önem düzeyinde anlamlı bir fark bulunmamıştır. $\mathrm{Bu}$ bulgu, öğrencilerin etkileşimli tahta tutum ölçeği puanları ile sınıf düzeyi arasında anlamlı bir fark olmadığını göstermektedir.

Öğrencilerin etkileşimli tahtaya yönelik tutum ölçeği puanlarının etkileşimli tahta ile öğrenim görme süresine göre farklılık gösterip göstermediğini anlamak amacıyla Tek Yönlü Varyans analizi (ANOVA) uygulanmış ve bulgular Tablo 5'teverilmiştir.
Tablo 5. Öğrencilerin Etkileşimli Tahta İle Öğrenim Görme Süresine Göre etkileşimli Tahtaya Yönelik Tutum Ölçeği Puanları Arasındaki Farka İlişkin Tek Yönlü Varyans Analizi Sonuçları (ANOVA)

\begin{tabular}{lcccccc}
\hline Gruplar & $\mathrm{N}$ & $\bar{X}$ & S.s. & $\mathrm{F}$ & $\mathrm{p}$ & Fark \\
\hline a-1 y1l & 72 & 79,9 & 14,6 & & & $\mathrm{c}-\mathrm{a}$ \\
b-2 y1l & 124 & 81,6 & 15,6 & 5,733 &, 004 & $\mathrm{c}-\mathrm{b}$ \\
c-3 y1l & 55 & 88,5 & 13,3 & & & \\
\hline
\end{tabular}

Tablo 5 incelendiğinde, öğrencilerin etkileşimli tahtaya yönelik tutum ölçeği puanları ile etkileşimli tahta ile öğrenim görme süresi arasındaki farka ait $\mathrm{F}$ değeri 5,733 olarak $\mathrm{p}<.05$ önem düzeyinde anlamlı bir fark bulunmuştur. $\mathrm{Bu}$ bulgu, öğrencilerin etkileşimli tahta ile öğrenim görme süresine göre etkileşimli tahtaya yönelik tutum ölçeği puanları arasında anlamlı farkın olduğunu göstermektedir. Anlamlı fakın hangi gruplar arasında olduğunu belirlemek amacıyla post-hoc testleri kullanılmıştır. Bu doğrultuda Levene's testi sonucuna bakılmıştır. Levene's test sonuçlarına $(p>0.50)$ ve örneklem sayılarına bakılarak Fisher LSD testi kullanılmasının daha uygun olabileceğine karar verilmiştir. Analizler sonucunda etkileşimli tahta ile öğrenim görme süresi 3 yıl olan öğrenciler ile diğer gruplar arasında etkileşimli tahta ile öğrenim görme süresi 3 yıl olan öğrencilerin lehine fark görülmüştür.

Öğrencilerin etkileşimli tahtaya yönelik tutum ölçeği puanlarının etkileşimli tahta kulanım sıklığına göre farklılık gösterip göstermediğini anlamak amaciyla Tek Yönlü Varyans analizi (ANOVA) uygulanmış ve bulgular Tablo 6'da verilmiştir.

Tablo 6. Öğrencilerin Etkileşimli Tahta Kulanım Sıklı̆̆ına Göre Etkileşimli Tahtaya Yönelik Tutum Ölçeği Puanları Arasındaki Farka İlişkin Tek Yönlü Varyans Analizi Sonuçları (ANOVA)

\begin{tabular}{lcccccc}
\hline Gruplar & $\mathrm{N}$ & $\bar{X}$ & S.s. & $\mathrm{F}$ & $\mathrm{p}$ & Fark \\
\hline Çok az & 9 & 74,5556 & 15,25706 & & & \\
Bazen & 121 & 81,9917 & 14,83661 & 1,378 &, 250 & - \\
S1klıkla & 104 & 84,3077 & 15,49762 & & & \\
Sürekli & 17 & 81,6471 & 14,67967 & & & \\
\hline
\end{tabular}

Tablo 6 incelendiğinde, öğrencilerin etkileşimli tahtaya yönelik tutum ölçeği puanları ile etkileşimli tahta kulanım sıklığı arasındaki farka ait $F$ değeri 1,378 olarak p>.05 önem düzeyinde anlamlı bir fark bulunmamıştır. $\mathrm{Bu}$ bulgu, öğrencilerin etkileşimli tahta kulanım sıklığına göre ölçekten elde puanları arasında anlamlı farkın olmadığını gösterir.

Öğrencilerin etkileşimli tahtaya yönelik tutum ölçeği puanlarının Görsel Sanatlar ders başarı algısına göre farklılık gösterip göstermediğini anlamak amacıyla Tek Yönlü Varyans analizi (ANOVA) uygulanmış ve bulgular Tablo 7'de verilmiştir.

Tablo 7. Öğrencilerin Görsel Sanatlar Ders Başarı Algısına Göre Etkileşimli Tahtaya Yönelik Tutum Ölçeği Puanları Arasındaki Farka İlişkin Tek Yönlü Varyans Analizi Sonuçları (ANOVA)

\begin{tabular}{|c|c|c|c|c|c|c|}
\hline $\begin{array}{l}\text { Görsel Sanatlar } \\
\text { Ders Başarı } \\
\text { Algıları }\end{array}$ & $\mathrm{N}$ & $\bar{X}$ & S.s & $\mathrm{F}$ & $\mathrm{p}$ & Fark \\
\hline Çok iyi & 50 & 83,3200 & 15,92000 & & & \\
\hline İyi & 117 & 83,6239 & 15,59218 & ,553 & 646 & - \\
\hline Orta & 59 & 81,0000 & 13,34296 & & & \\
\hline Kötü & 25 & 80,7600 & 15,91456 & & & \\
\hline
\end{tabular}


Tablo 7 incelendiğinde, öğrencilerin etkileşimli tahtaya yönelik tutum ölçeği puanları ile Görsel Sanatlar ders başarı alg1s1 arasındaki farka ait $\mathrm{F}$ değeri ,553 olarak $\mathrm{p}>.05$ önem düzeyinde anlamlı bir fark bulunmamıştır. $\mathrm{Bu}$ bulgu, öğrencilerin Görsel Sanatlar ders başarı algısına göre etkileşimli tahtaya yönelik tutum ölçeği puanları arasında anlamlı farkın olmadığını gösterir.

\section{Tartışma, Sonuç ve Öneriler}

Görsel Sanatlar dersinde etkileşimli tahtaya yönelik tutum ölçeğinden öğrencilerin aldıkları puanların ortalaması 82,66'dır. Bu bulgulardan hareketle öğrencilerin etkileşimli tahtaya yönelik tutumlarının olumlu yönde ve orta düzeyde olduğu sonucuna ulaşılmıştır. Bu sonuç, bu konuda yapılan diğer araştırma sonuçları ile paralellik göstermektedir. Özhan (2012) yüksek lisans tez araştırmasında öğrencilerin akıllı tahtaya yönelik tutumlarının olumlu yönde ve oldukça yüksek düzeyde olduğunu ortaya koymaktadır. Tataroğlu (2009) yaptığı çalışmada ise öğrencilerin akıllı tahtaya karşı tutumlarının orta düzeyde ve pozitif olduğunu dile getirmiştir. Tatlı ve Kılıç (2013); Bağcı (2013); Temelli ve Genç (2014); Hall ve Higgins (2005); Pamuk, Çakır, Yılmaz ve Ayas'ın (2013) yaptıkları çalışmalarda ise akıllı tahta ile ilgili genel olarak olumlu bir tutumun sergilendiği belirtmektedir. Sünkür, Arabacı ve Şanlı (2012) tarafindan yapılan araştırma, öğrencilerin akıllı tahtaları kullanmaktan keyif aldıklarını ve akıllı tahtaların onların ilgisini çektikleri gibi bulgulara sahiptir.

Öğrencilerin etkileşimli tahtaya yönelik tutumlarının cinsiyet değişkenine göre anlamlı olarak farklılaşıp farklılaşmadığını belirlemek için yapılan bağımsız örneklem t-testi sonucunda aradaki farkın anlamlı olmadığ bulunmuştur ( $\mathrm{t}=1,474, \mathrm{p}>.05)$. Tataroğlu (2009) yaptığı araştırmada öğrencilerin akıllı tahtaya yönelik tutumları cinsiyet değişkenine göre istatistiksel olarak anlamlı bir fark olmadığını belirtmiştir. Bu durum, araştırma sonuçları ile paraleldir. Fakat erkek öğrencilerin etkileşimli tahtaya yönelik tutumlarının kız öğrencilerinkinden daha yüksek çıkması yapılan araştırma sonuçlarıyla kısmen çelişmektedir. Temelli ve Genç (2014) yapmış oldukları çalışmada kadın ve erkek öğretmenlerin akıllı tahtaya yönelik tutumlarında istatistiksel olarak anlamlı farklılık bulunmadığını belirtmişılerdir. $\mathrm{Bu}$ durum, araştırmacının yapmış olduğu çalışmanın sonuçlarıyla paralellik göstermektedir. Fakat erkek öğretmenlerin akıllı tahtaya yönelik tutumlarının kadın öğretmenlerin akıllı tahtaya yönelik tutumlarından yüksek çıkması yapılan araştırma sonuçlarıyla kısmen çelişirken Tataroğlu (2009) tarafindan yapılan çalışmayla örtüşmektedir. Literatürde yaralan Bağcı (2013); Öğreten ve Uluçınar Sağır (2013); Türel (2012); Özhan (2012); Temelli ve Genç (2014); Tataroğlu (2009) gibi pek çok araştırma, araştırmacının yapmış olduğu çalışmanın sonuçlarıyla paralellik göstermektedir.

Öğrencilerin etkileşimli tahtaya yönelik tutum ölçeği puanlarının sınıf düzeyine göre varyans analizi sonuçları incelendiğinde, $\mathrm{F}$ değeri ,672 olarak p $>.05$ önem düzeyinde anlamsız bulunmuştur. Bu bulguyla öğrencilerin etkileşimli tahtaya yönelik tutum ölçeği puanlarının sınıf düzeyine göre aralarında fark olmadığı sonucuna ulaşılmıştır Özhan'nın (2012) yaptığı çalışmada da benzer sonuçlar elde edilmiştir. Bağcı (2013) yapmış olduğu çalışmada öğrencilerin akıllı tahtaya yönelik görüşlerinin sınıf düzeyi değişkenine göre istatistiksel olarak anlamlı farklılık göstermediğini dile getirmiştir. $\mathrm{Bu}$ durum, yapmış olduğumuz çalışmayla örtüşmektedir. Şerefhanoğlu'nun (2007) yapmış olduğu çalışmada ise öğrencilerin tutumlarının sınıf düzeyinin artması ile biraz düştüğü yönünde bir sonuç elde edilmiştir.

Öğrencilerin etkileşimli tahtaya yönelik tutum ölçeği puanları etkileşimli tahta ile öğrenim görme süresi değişkenine göre varyans analizi sonuçları incelendiğinde, $F$ değeri 5,733 olarak $\mathrm{p}<.05$ önem düzeyinde anlaml bulunmuştur. $\mathrm{Bu}$ bulgu öğrencilerin etkileşimli tahta ile öğrenim görme süresine göre etkileşimli tahtaya yönelik tutum ölçeği puanları arasında farkın olduğunu gösterir. Akıllı tahta ile öğrenim görme süresi değişkenine göre öğrencilerin akıllı tahtaya yönelik tutum ölçeği puanları aritmetik ortalamalarında genellikle kulanım süresine paralel olarak artış göstermiştir. Benzer bir sonucu Özhan (2012) ve Elaziz (2008) yapmış oldukları çalışmalarda da ortaya koymuşlardır.

Öğrencilerin etkileşimli tahtaya yönelik tutum ölçeği puanları etkileşimli tahta kulanım sıklığına göre varyans analizi sonuçları incelendiğinde, F değeri 1,378 olarak p>.05 önem düzeyinde anlamsız bulunmuştur. $\mathrm{Bu}$ bulgu, öğrencilerin etkileşimli tahta kulanım sıklığına göre etkileşimli tahtaya yönelik tutum ölçeği puanları arasında farkın olmadığını gösterir. Elaziz (2008) tarafından yapılan çalışmada, öğrencilerin akıllı tahtaya yönelik tutum ölçeği toplam puanlarının kullanım süresine göre anlamlı farklılık gösterdiği belirtilerek akıllı tahtayı sık kullananların tutumlarının daha yüksek olduğu dile getirilmiştir. Özhan (2012) yapmış olduğu çalışmada ise akıllı tahtaya yönelik tutum ölçeği toplam puanlarının akıllı tahta kullanım sıklığına göre anlamlı farklılık göstermediğini dile getirmiştir. $\mathrm{Bu}$ bulgu, araştırmacının yapmış olduğu çalışmayla örtüşmektedir.

Öğrencilerin etkileşimli tahtaya yönelik tutum ölçeği puanları ile Görsel Sanatlar ders başarı algısı değişkeni arasında yapılan analiz sonuçlarına göre anlamlı bir fark olmadığı sonucuna ulaşılmıştır. Görsel Sanatlar ders başarı alg1 düzeyleri düştükçe öğrencilerin tutum ölçeği puanlarında aritmetik ortalamaların azaldığı görülmektedir. Sonuç olarak Görsel Sanatlar ders başarı algı düzeyleri arttıkça ögrencilerin etkileşimli tahtaya yönelik tutumlarının da arttığ1 söylenebilir. Literatürde rastlanan pek çok araştırmada ders başarısının etkileşimli tahtaya yönelik tutumu etkisinden çok etkileşimli tahtanın ders başarısına etkisinin incelendiği görülmüştür. Ekici (2008) yapmış olduğu yüksek lisans tez çalışmasında, etkileşimli tahta kullanımının öğrencilerinin ders başarılarına etki ettiği sonucuna ulaşmıştır. Tataroğlu (2009) da yapmış olduğu çalışmada benzer bir sonuç ortaya koymaktadır. Altınçelik (2009); Akgül (2013); Olgun (2012); Kaya ve Aydın (2011); Ateş (2010); Elaziz (2008); Yorgancı ve Terzioğlu (2013); Öğreten ve Uluçınar Sağır (2013) tarafından yapılan birçok araştırmada derslerde etkileşimli tahta kullanımının ders başarısına etkisinin olduğunu göstermektedir. Araştırmadan elde edilen sonuçlara bağlı olarak bazı öneriler şu şekilde siralanabilir:

(i) Öğrenciler, etkileşimli tahtalara karşı olumlu tutum sergiledikleri için Görsel Sanatlar derslerinde akıllı tahta aktif olarak kullanılmalıdır.

(ii) Etkileşimli tahtalara yönelik Görsel Sanatlar derslerine uygun ders materyalleri geliştirilmelidir. 
(iii) Görsel Sanatlar dersinde etkileşimli tahta kullanımı için farklı bir program oluşturulmalıdır.

(iv) $\mathrm{Bu}$ araştırma, Görsel Sanatlar derslerinde orta öğretim öğrencilerinin etkileşimli tahtaya yönelik tutumlarının incelenmesi üzerinedir. Diğer sınıflarda çalışma grubu olarak veli ya da yöneticilerle de benzer veya farklı çalışmalar yapılabilir.

(v) Görsel Sanatlar derslerinde öğrencilerin etkileşimli tahtaya yönelik tutumları üzerine yapılan bu çalışma, daha büyük örneklem gruplara veya farklı sosyoekonomik düzeylerdeki okullarda araştırmalar şeklinde yapılabilir.

\section{Kaynakça}

Agyeman, C. A. (2015). Artists' perception of the use of digital media in painting. Doctoral dissertation. Ohio: Ohio University.

Akgül, B. (2013). Illkögrretim görsel sanatlar dersinde akullı tahta kullanımının öğrenci başarısına etkisi. Yüksek Lisans Tezi. Ankara: Gazi Üniversitesi.

Altınçelik, B. (2009). Illköğretim düzeyinde öğrenmede kalıcılığ ve motivasyonu sağlaması yönünden akıllı tahtaya ilişkin ögrretmen görüşleri. Yüksek Lisans Tezi. Sakarya: Sakarya Üniversitesi.

Armstrong, V., Barnes, S., Sutherland, R., Curran, S., Mills, S., \& Thompson, I. (2005). Collaborative research methodology for investigating teaching and learning: the use of interactive whiteboard technology. Educational review, 57(4), 457-469.

Artut, K. (2009). Sanat Ĕgitimi Kuramları ve Yöntemleri. (6.Baskı) Ankara: Anı Yayıncılı.

Ateş, M. (2010). Ortaöğretim coğrafya derslerinde akılllı tahta kullanımı. Marmara Üniversitesi Coğrafya Dergisi,22, 409-427.

Athanasiadis, I., Maria, K., \& Efstathios, S. (2011). Students' views on the use of new technologies in art education: An interdisciplinary approach to higher education. Review of European Studies, 3(1), 60.

Avc1, E. (2013). Dijital Sanat Bağlamında Dijital Teknolojilerin Güzel Sanatlar Eğitimine Entegrasyonu: Bir Eylem Araştırması. Doktora Tezi. Eskişehir: Anadolu Üniversitesi.

Bağc1, H. (2013). Fatih Projesi çerçevesinde ortaöğretim öğrencilerinin etkileşimli tahtaya yönelik görüşlerinin incelenmesi. Yüksek Lisans Tezi. İstanbul: Okan Üniversitesi.

Balta, N., \& Duran, M. (2015). Attitudes of students and teachers towards the use of interactive whiteboards in elementary and secondary school classrooms. TOJET: The Turkish Online Journal of Educational Technology, 14(2), 15-23.

Bell, M. A. (1998). Teachers' Perceptions Regarding the Use of the Interactive Electronic Whiteboard in Instruction. (Accessed on 03.06.2014), 12/teachers_perceptions_regarding_the_use_of_the_inte ractive_electronic_whiteboard_in_instruction.pdf
Birișçi, S., \& Karal, H. (2010). Bilgisayar öğretmeni adaylarının eğitimde bilgisayar animasyonlarının kullanılabilirliği hakkındaki görüşleri. New World Sciences Academy, 5(4), 1613-1627.

Değerli, A. S. (2015). Güzel sanatlar ve eğitim fakültelerinde resim eğitimi alan öğrencelerin sanat eğitim sürecindeki teknoloji algilart. Doktora Tezi. Samsun: Ondokuz Mayıs Üniversitesi.

Ekici, F. (2008). Akıllı tahta kullanımının ilköğretim öğrencilerinin matematik başarılarına etkisi. Yüksek Lisans Tezi. İstanbul: Marmara Üniversitesi.

Elaziz, F. M. (2008). Attitudes of students and teachers towards the use of interactive whiteboards in EFL classrooms. Master Thesis. Ankara: Bilkent University.

Engin, A.O., Tösten, R., \& Kaya, M.D. (2010). Bilgisayar destekli eğitim. Journal of the Institute of Social Sciences, 5, 69-80.

Erduran, A., \& Tataroğlu, B. (2009). Eğitimde Akıllı Tahta Kullanımına İlişkin Fen ve Matematik Öğretmen Tutumlarının Karşılaştırılması. İçinde: 9th International Educational Technology Conference (IETC2009), 14-21.

Güzeller, C., \& Korkmaz, Ö. (2007). Bilgisayar destekli öğretimde bir ders yazılımı değerlendirmesi. Kastamonu Eğitim Dergisi, 15(1), 155-168.

Halis, İ. (2002). Öğretim Teknolojileri ve Materyal Geliştirme. Ankara: Nobel Yayın Dağıtım.

Hall, I., \& Higgins, S. (2005). Primary school students perception of interactive whiteboards. Journal of Computer Assisted Learning, 21(2), 102-117.

Hançer, A. H. (2005). Fen eğitiminde yapılandırmacı yaklaşıma dayalı bilgisayar Destekli öğrenmenin ögrenme ürünleri üzerine etkisi. Doktora Tezi. Ankara: Gazi Üniversitesi.

Hiçyılmaz, Y., \& İnam Karahan, Ç. (2016). Görsel sanatlar öğretmen ve öğretmen adaylarının öğretim teknolojilerine yönelik görüşleri. İçinde: Ö. Demirel ve S. Dinçer (Ed.), Eğitim bilimlerinde yenilikler ve nitelik arayışı, (s. 953-966). Ankara: Pegem Akademi Yayınları.

Hiçyılmaz, Y., \& Kayserili, M. E. (2017). Görsel sanatlar dersinde akıllı tahta kullanımına ilişkin öğretmen görüşlerinin incelenmesi. Atatürk Üniversitesi Kazım Karabekir Eğitim Fakültesi Dergisi, (35), 56-75.

Karasar, N. (1991). Bilimsel Araştırma Yöntemi. Ankara: Sanem.

Kaya, H., \& Aydın, F. (2011). Sosyal bilgiler dersindeki coğrafya konularının öğretiminde akıllı tahta uygulamalarına ilişkin öğrenci görüşleri. Journal of World of Turks, 3(1), 179-189.

Kennewell, S., \& Morgan, A. (2003). Student teachers' experiences and attitudestowards using interactive whiteboards in the teaching and learning of young children. (Erişim Tarihi: 6.6.2014), http://crpit.com/confpapers/CRPITV34Kennewell1.pdf

Koşar, E., \& Çiğdem H. (2003). Eğitim Ortamı Tasarımı, Araç-Gereç ve Materyal Özellikleri. Öğretim 
Teknolojileri ve Materyal Geliștirme. Ankara: Öğreti Pegem A Yayıncilik.

Kuzminsky, T.V. (2008). Interactive whiteboard technology within the kindergarten visual art classroom. Masters Thesis. Georgia State University.

Lau, I. (2011). Teachers for "Smart Classrooms": The Extent of Implementation of an Interactive Whiteboard-based Professional Development Program on Elementary Teachers' Instructional Practices. Interdisciplinary Journal of ELearning \& Learning Objects, 7, 275-289.

Levy, P. (2002). Interactive Whiteboards in learning and teaching in two Sheffield schools: a developmental study. (Accessed on 12.04.2014), http://dis.shef.ac.uk/eirg/projects/wboards.htm,

Manny-Ikan, E., Dagan, O., Tikochinski, T., \& Zorman, R. (2011). [Chais] Using the Interactive White Board in Teaching and Learning-An Evaluation of the SMART CLASSROOM Pilot Project. Interdisciplinary Journal of E-Learning and Learning Objects, 7(1), 249-273.

Odabaş1, H.F. (Editör). (2010). Bilgi Ve İletişim Teknolojileri Işı̆̆̆ıda Dönüşümler. Ankara: Nobel Akademik Yayıncılık.

Olgun, H. (2012). Fizik dersinde ortaöğretim öğrencilerinin akıllı tahta kullanımı ile ilgili algılarının araştırılması. Yüksek Lisans Tezi. İstanbul: Marmara Üniversitesi.

Öğreten, B., \& Uluçınar Sağır, Ş. (2013) 4. Sınıf Fen ve Teknoloji dersinde interaktif öğretimin akademik başarıya ve tutuma etkisi. Batı Anadolu Eğitim Bilimleri Dergisi, 04 (07), 2013, 1-18.

Özhan, U. (2012). İlköğretim öğrencilerinin öğrenme stilleri ile derslerindeki akıllı tahta kullanımına yönelik görüşleri arasındaki ilişkinin incelenmesi. Yüksek Lisans Tezi. Elâzığ: Fırat Üniversitesi.

Pamuk, S., Çakır, R., Ergun, M., Yılmaz, H. B., \& Ayas, C. (2013). Öğretmen ve öğrenci bakış açısıyla tablet PC ve etkileşimli tahta kullanımı: FATİH Projesi değerlendirmesi. Kuram ve Uygulamada Ĕgitim Bilimleri, 13(3), 1799-1822. http://dx.doi.org/10.12738/estp.2013.3.1734

Pamuk, S., Çakır, R., Yılmaz H.B.i ve Ayas, C. (2013). Öğretmen ve öğrenci bakışıcısıyla tablet pc ve etkileşimli tahta kullanımı: FATİH Projesi değerlendirmesi kuram

Polat, S., \& Özcan, A. (2014). Akıllı tahta kullanımıyla ilgili sınıf öğretmenlerinin görüşleri. Kastamonu Ĕ̌itim Dergisi, 22(2), 439-455.

Sünkür, M., Arabacı, İ. B., \& Şanlı, Ö. (2012). Akıllı tahta uygulamaları konusunda ilköğretim 11. kademe öğrencilerinin görüşleri (Malatya ili örneği). E-Journal of New World Sciences Academy (NWSA), 7(1), 313-321.

Şerefhanoğlu, H. (2007). Illköğretim II. kademe ögrencilerinin bilgisayara yönelik tutumları ile oklu zekâ alanlarının karşılaştırılması. Yüksek Lisans Tezi. Balıkesir: Balıkesir Üniversitesi.

Tataroğlu, B. (2009). Matematik ögrretiminde akıllı tahta kullanımının 10. sınıf ögrencilerinin akademik başarlları, matematik dersine karşı tutumları ve öz- yeterlik düzeylerine etkileri. Yüksek Lisans Tezi. İzmir: Dokuz Eylül Üniversitesi.

Tatlı, C., \& Kılıç, E. (2013). Etkileşimli tahtaların kullanımına ilişkin alınan hizmet içi eğitimin öğretmen görüşleri doğrultusunda değerlendirmesi. Ĕ̆itim Bilimleri ve Uygulama, 12 (24), 137-158.

Temelli, D., \& Genç, S. Z. (2014). Akıllı tahtaya yönelik öğretmen tutumları (Çanakkale ili örneği). Pegem Ĕgitim ve Öğretim Dergisi, 4(4), 41-58.

Terreni, L. (2011). Interactive whiteboards, art and young children. Computers in New Zealand Schools: learning, teaching, technology, 23(10), 1-23.

Thompson, J., \& Flecknoe, M. (2003). Raising attainment with an interactive whiteboard in Key Stage 2. Management in Education, 17(3), 29-33.

Türel, Y. K., \& Johnson, T. E. (2012). Teachers' belief and use of interactive whiteboards for teaching and learning. Journal of Educational Technology \& Society, 15(1), 381-394.

Yalın, H. Ġ. (2010). Öğretim Teknolojileri ve Materyal Geliştirme. Ankara: Nobel Yayın Dağıtım.

Yıldırım, A., \& Şimşek, H. (2006). Sosyal Bilimlerde Nitel Araştırma Yöntemleri. Ankara: Seçkin Yayıncılık.

Yılmaz, E. M., \& Bilici, S. (2016). Görsel sanatlar alanına yönelik öğretim teknolojileri ve materyali durumu. Muğla Sitkı Koçman Üniversitesi Eğitim Fakültesi Dergisi, 3(1), 64-74

Yorganc1, S., \& Terzioğlu, Ö. (2013). Matematik öğretiminde akıllı tahta kullanımının başarıya ve matematiğe karşı tutuma etkisi. Kastamonu Ĕ̆itim Dergisi, 21(3), 919-930.

Zor, A. (2008). Yapılandırmacı yaklaşıma göre web tabanlı bilgisayar destekli sanat eğitimi. Yüksek Lisans Tezi. Anlara: Gazi Üniversitesi. 